\section{Systematic Relationship of Weeping Katsura Based on Nuclear Ribosomal DNA Sequences}

\author{
Jianhua Li ${ }^{1}$, Michael S. Dosmann ${ }^{2}$, and Peter Del Tredici ${ }^{3}$ \\ The Arnold Arboretum of Harvard University, 125 Arborway, Jamaica Plain, \\ MA 02130
}

Susyn Andrews ${ }^{1}$
Herbarium, Royal Botanic Gardens, Kew, Richmond, Surrey TW9 3AE,
United Kingdom

Additional index words. Cercidiphyllum japonicum, Cercidiphyllum magnificum, ITS, sequence divergence, taxonomy

\begin{abstract}
Sequences of the internal transcribed spacers (ITS) of nuclear ribosomal DNA were used to examine genetic divergence of the two species of katsura [Cercidiphyllum japonicum Sieb. \& Zucc. and Cercidiphyllum magnificum (Nakai) Nakai] and four clones of weeping katsura ('Amazing Grace', 'Tidal Wave', 'Pendulum', and 'Morioka Weeping'), and to characterize the affinity of these weeping katsura to both species. Our results indicate that $C$. japonicum and $C$. magnificum are genetically distinct, supporting the recognition of them as separate species. Based on our DNA sequence data and morphological evidence, all weeping selections are phylogenetically derived from $C$.japonicum, not $C$. magnificum; nor are they of a hybrid origin between $C$. japonicum and $C$. magnificum. We propose the new cultivar-group Cercidiphyllum japonicum Weeping Group to include all katsura clones of weeping or pendulous habit, and recognize the cultivar epithet 'Morioka Weeping' and its application to the excurrent and upright clone obtained from Japan and distributed in North America by the Arnold Arboretum.
\end{abstract}

Cercidiphyllum (Cercidiphyllaceae), a genus endemic to Japan and China, includes two species of dioecious trees with opposite, rounded, simple, petiolate leaves. Staminate flowers are axillary, subsessile, solitary or fascicled; pistillate flowers are solitary, axillary, pedicellate, and have four to six carpels that develop into small, banana-shaped follicles. Cercidiphyllum japonicum Sieb. \& Zucc. of Japan and China is widely cultivated as an ornamental. This species is commonly known as katsura and lian xian shu, in Japan and China, respectively. Cercidiphyllum magnificum (Nakai) Nakai, the hiro-ha-katsura (or broad-leaved katsura) of Japan, is a rare plant and also has many ornamental attributes, as described by Haag (1982) and Dosmann (2000).

Cercidiphyllum is systematically isolated, and has been treated as a distinct monoge-

\footnotetext{
Received for publication 2 July 2001. Accepted for publication 21 Nov. 2001. We thank the following for providing living and dried plant material for this study: Bernheim Arboretum and Research Forest, Clermont, Ky.; Chicago Botanic Garden, Glencoe, Ill.; Lorax Farms, Warrington, Pa.; Quarryhill Botanic Garden, Glen Ellen, Calif.; Ringve Botanic Garden, Trondheim, Norway; and Royal Botanic Garden, Edinburgh, Scotland. We also thank Jeff Iles, Mark Widrlechner, and two anonymous reviewers for their helpful comments and suggestions. ${ }^{1}$ Horticultural Taxonomist.

${ }^{2}$ Putnam Research Fellow.

${ }^{3}$ Director of Living Collections.
}

neric family or order (Endress, 1986; Harms, 1916). Based on both morphological and molecular evidence, Cercidiphyllaceae is generally considered most closely related to Daphniphyllaceae and Hamamelidaceae (Angiosperm Phylogeny Group, 1998; Harms, 1916; Manos et al., 1993; Qiu et al., 1998, 1999; Soltis and Soltis, 1997).

Within Cercidiphyllum, however, the taxonomy is less clear. Cercidiphyllum japonicum was first described from Japan (Hoffman and Schultes, 1853), and is the best-known species of the genus. Nakai (1919) published a second variety, C. japonicum var. magnificum Nakai, that was raised to specific status the following year (Nakai, 1920). In Japan, C. japonicum is widely distributed up to $1000 \mathrm{~m}$ above sea level in Hokkaido, Honshu, Shikoku, and Kyushu, while the rarer $C$. magnificum is confined to higher elevations (1000 to 2800 $\mathrm{m})$ of central and northern Honshu. These two species are rarely sympatric and, even in places where both species occur, no intermediate forms have been found (Lindquist, 1954). Cercidiphyllum magnificum has smooth bark (vs. deeply furrowed), broadly crenate leaf margins (vs. crenate to serrulate margins), overlapping short-shoot basal leaf lobes (vs. non-overlapping), partially splitting follicles with strongly recurved apices (vs. splitting follicles with slightly recurved apices), yellowish-white seeds (vs. tan-colored seeds), and seeds winged at both ends (vs. seeds winged at the proximal ends). Though $C$. magnificum is accepted by many (Andrews, 1998; Dosmann, 1999; Krüssmann, 1965;
Spongberg, 1979), it is treated as a variety by others (Bean, 1970; Flint, 1997; Griffiths, 1994).

All pendulous or weeping katsura (known as shidare-katsura in Japan) were originally placed within $C$. japonicum, being described as $C$. japonicum var. pendulum Miyoshi (Makino, 1931). Later, this taxon was treated as a form by Ohwi (1953): C. japonicum forma pendulum (Miyoshi) Ohwi. Spongberg (1979) then recombined all weeping katsura to $C$. magnificum forma pendulum (Miyoshi) Spongberg. At the time, Spongberg (1979) hypothesized that weeping trees might be hybrids between the two species, although this theory was later refuted (Andrews, 1998).

Documented cultivation of weeping katsura dates back to between 1576 and 1635, when a weeping Cercidiphyllum was found by a priest in a forest in Iwate Prefecture, Japan, and brought to the grounds of the Ryugenzi Temple at Ohgayu near Morioka (Lancaster, 1997; Miyoshi, 1936). Subsequent clonal propagation of this tree, or possible reintroductions from the original natural stand (if it existed), led to the establishment of these trees as landmarks in local temples. Their pendulous yet excurrent growth habit and form are easily recognizable. In more recent times, weeping katsura of rounded form and lacking central leaders have been cultivated in North America and Europe.

Koller (1987) acknowledged variation among weeping katsura trees and refers to cultivars ('Pendulum') of both species. Those he described as C. magnificum 'Pendulum' represent clonal material acquired from an historic monumental tree near Morioka, Japan, in 1981 by the Arnold Arboretum, which was subsequently propagated and distributed. This represented the upright and excurrent genotype that can reach upwards of $30 \mathrm{~m}$ in height. What Koller described as C.japonicum 'Pendulum', on the other hand, predated the former clone in North American cultivation, was rounded in form, less vigorous, and generally grafted several meters high on seedling stems. Dirr (1998) noted that weeping $C$. japonicum 'Pendula' (sic) and C. magnificum 'Pendulum' are both common in commerce at the present time.

Genotypes other than the cultivars 'Pendulum' are also available in the trade and represent both weeping habits. Recently released 'Amazing Grace' is a selection discovered by the late Theodore Klein of Yew Dell Nursery, Crestwood, Ky., around 1960 (Cappiello, 1999). Another weeping clone of similar origin is 'Tidal Wave', discovered by H. William Barnes of Lorax Farms, Warrington, Pa. (Barnes, 1995). Both of these named selections were found among seedlings of $C$. japonicum and become rounded in form. Del Tredici (2000) applied the name 'Morioka Weeping' to the excurrent genotype described by Koller (1987) as C. magnificum 'Pendulum' and distributed by the Arnold Arboretum.

The debate over the legitimacy of the two species, and the various (re)classifications of weeping trees, has resulted in much confusion pertaining to the classification and nomencla- 
ture of pendulous katsura. The object of this investigation was to answer the following questions concerning Cercidiphyllum: 1) Are $C$. magnificum and $C$. japonicum genetically distinct species? 2) To what species do the weeping clones of Cercidiphyllum belong? and 3) Are the weeping Cercidiphyllum of hybrid origin between $C$. magnificum and $C$. japonicum? We chose to use sequences of the Internal Transcribed Spacer (ITS) region of nuclear ribosomal DNA since this region has been successfully used to investigate genetic relationships of plant groups at the species level (Baldwin et al., 1995; Gould and Donoghue, 2000; Li et al., 2000; Padgett et al., 1999). The development of molecular biology has generated useful DNA markers that have been applied to an array of systematic problems. Recent studies related to cultivated plants include an analysis of the genetic diversity of Loropetalum chinense (R. Br.) Oliv. var. rubrum Yieh. (Gawel et al., 1996); parentage determination of the Pfitzer Group of juniper cultivars [Juniperus $\times$ pfitzeriana (Späth) Schmidt] (Le Duc et al., 1999); and parentage determination of the hybrid Stewartia X 'Scarlet Sentinel’ (Del Tredici and Li, 2002).

\section{Materials and Methods}

Plants. Eleven individual plants were sampled, representing $C$. japonicum, $C$. magnificum, and four weeping cultivars (Table 1). Individuals representing both species include those of cultivated and wild origin, and the weeping cultivars represent four unique introductions. Voucher specimens have been deposited at the Arnold Arboretum.

Molecular techniques. DNAs were extracted from silica-gel dried leaves or buds by using a Qiagen DNeasy Mini Kit (Santa Clarita, Calif.), following the manufacturer's protocol. Polymerase chain reaction (PCR) was conducted with primers ITS4 (White et al., 1990) and ITSLeu (Baum et al., 1998) to amplify the entire ITS region of nrDNA in a Perkin-Elmer 2400 or 9600 Thermocycler. The PCR protocols are described in detail in $\mathrm{Li}$ et al. (2000). PCR products were then visualized with ethidium bromide under an ultraviolet transilluminator and purified using a Qiagen PCR purification kit. Sequencing reactions were carried out with a Cycle Sequencing Kit following the manufacturer's protocol (Applied Biosystems, La Jolla, Calif.). Sequences

Table 1. Acronyms, voucher, and source information of Cercidiphyllum japonicum, Cercidiphyllum magnificum, and weeping Cercidiphyllum studied.

\begin{tabular}{|c|c|c|}
\hline Species or weeping cultivar & Acronym & Voucher source, accession number, and origin \\
\hline \multirow[t]{4}{*}{ Cercidiphyllum magnificum } & CME18 & $\begin{array}{l}\text { Royal Botanic Garden Edinburgh, \#19952918, from } \\
\text { Honshu, Japan }\end{array}$ \\
\hline & CME19 & $\begin{array}{l}\text { Royal Botanic Garden Edinburgh, \#19952919, from } \\
\text { Honshu, Japan }\end{array}$ \\
\hline & CMRGV & $\begin{array}{l}\text { Ringve Botanic Garden, Norway, Index Seminum, } \\
\text { cultivated origin }\end{array}$ \\
\hline & CMKEW & $\begin{array}{l}\text { Royal Botanic Gardens, Kew, \#1946-13603, cultivated } \\
\text { origin }\end{array}$ \\
\hline \multirow[t]{3}{*}{ Cercidiphyllum japonicum } & CJA98 & $\begin{array}{l}\text { Arnold Arboretum, Mass., \#19-98A, from Hokkaido, } \\
\text { Japan }\end{array}$ \\
\hline & CJQBG & $\begin{array}{l}\text { Quarryhill Botanic Garden, Calif., \#1992.311, from } \\
\text { Sichuan, China }\end{array}$ \\
\hline & CJA87 & Arnold Arboretum, Mass., \#178-87C, cultivated origin \\
\hline 'Amazing Grace' & $\mathrm{CAG}$ & $\begin{array}{l}\text { Bernheim Arboretum and Research Forest, Ky., } \\
\text { \#1976-0012-00, cultivated origin from Yew Dell } \\
\text { Nursery, Ky. }\end{array}$ \\
\hline 'Morioka Weeping' & CMW & $\begin{array}{l}\text { Arnold Arboretum, Mass., \#697-81A, cultivated origin } \\
\text { from Morioka, Japan }\end{array}$ \\
\hline 'Pendulum’ & CCBG & $\begin{array}{l}\text { Chicago Botanic Garden, Ill., \#1639-91, cultivated } \\
\text { origin from the Holden Arboretum, Ohio }\end{array}$ \\
\hline 'Tidal Wave' & CTW & $\begin{array}{l}\text { Arnold Arboretum, Mass., \#230-2000, cultivated origin } \\
\text { from Lorax Farms, Pa. }\end{array}$ \\
\hline
\end{tabular}

were analyzed using an ABI 377 Automated DNA Sequencer (La Jolla, Calif.), and were edited using Sequencher 3.0 (Gene Codes Corp., Ann Arbor, Mich.). To verify base calling, we assembled and compared sequence chromatograms obtained from primers of opposite directions using Sequencher 3.0. Sequences were then imported into PAUP* version 4.0b7 (Swofford, 2000) and were aligned readily by eye. Limits of the ITS-1, $5.8 \mathrm{~S}$, and ITS-2 were determined by comparing published sequences in the GenBank (Li et al., 1999). The UPGMA (Unweighted Pair Group Method with Arithmetic mean) was used to generate a phylogram showing genetic relationships of Cercidiphyllum. To assess support for these relationships, we conducted bootstrap analysis (Felsenstein, 1985) using 10,000 replicates. All of these analyses were implemented in PAUP*.

\section{Results}

Sequence characteristics. Sequences of the ITS region including the $5.8 \mathrm{~S}$ gene were 675 base pairs (bp) in length in $C$. japonicum, and 673 bp in C. magnificum. The alignment, requiring one indel of two base pairs, generated a data set of 675 characters, 30 of which were variable (Table 2). The entire sequence is available upon request. Sequences of this region varied little among accessions within each of these two species $(0 \%$ to $0.7 \%)$, whereas between $C$. japonicum and $C$. magnificum sequence divergence ranged from $3.4 \%$ to $4 \%$ (Table 3). The four weeping cultivars showed virtually identical ITS sequences with $C$. japonicum, and variation within these four cultivars was within the variation of this species (Table 2).

Genetic relationships. The UPGMA analysis generated a phylogram (Fig. 1) displaying two major clusters. The first comprises the four accessions of $C$. magnificum, and the other contains accessions of $C$. japonicum and all weeping cultivars. This relationship is supported by the two-base indel at positions 204205. A weeping accession from Chicago Botanic Garden, CCBG, clustered with, but differed slightly from, the other $C$. japonicum accessions.

Table 2. Variable sites of sequences of nrDNA ITS in Cercidiphyllum japonicum, Cercidiphyllum magnificum, and weeping Cercidiphyllum. Acronyms for samples are listed in Table 1. Ambiguous sites for $\mathrm{C} / \mathrm{T}, \mathrm{A} / \mathrm{G}$, and $\mathrm{C} / \mathrm{G}$ are represented by $\mathrm{Y}, \mathrm{R}$, and $\mathrm{S}$, respectively.

\begin{tabular}{|c|c|c|c|c|c|c|c|c|c|c|c|c|c|c|c|c|c|c|c|c|c|c|c|c|c|c|c|c|c|c|}
\hline \multirow[b]{2}{*}{ Sample } & \multicolumn{30}{|c|}{ Nucleotide Site } \\
\hline & 13 & 33 & 345 & & 63 & 66 & 99 & 106 & 109 & 117 & 126 & 134 & 146 & 200 & 208 & 458 & 460 & 468 & 472 & 476 & 488 & 497 & 515 & 516 & 537 & 591 & 623 & 628 & 636 & 656 \\
\hline$\overline{\mathrm{CME} 18}$ & $\mathrm{~T}$ & $\mathrm{C}$ & $\mathrm{YC}$ & $\bar{G}$ & $\mathrm{G}$ & $\mathrm{T}$ & $\mathrm{T}$ & $\mathrm{C}$ & $\mathrm{T}$ & $\mathrm{G}$ & $\bar{G}$ & $\mathrm{~T}$ & $\mathrm{C}$ & $\mathrm{C}$ & $\mathrm{T}$ & $\mathrm{G}$ & $\mathrm{G}$ & $\mathrm{T}$ & $\mathrm{T}$ & $\mathrm{T}$ & $\mathrm{T}$ & $\mathrm{T}$ & $\mathrm{C}$ & $\mathrm{T}$ & $\mathrm{T}$ & $\mathrm{T}$ & $\mathrm{T}$ & $\mathrm{T}$ & $\mathrm{C}$ & $\overline{\mathrm{T}}$ \\
\hline CME19 & $\mathrm{T}$ & $\mathrm{C}$ & Y & G & $\mathrm{G}$ & $\mathrm{T}$ & $\mathrm{T}$ & $\mathrm{C}$ & $\mathrm{T}$ & S & G & $\mathrm{T}$ & $\mathrm{C}$ & $\mathrm{C}$ & $\mathrm{T}$ & G & $\mathrm{G}$ & $\mathrm{T}$ & $\mathrm{T}$ & $\mathrm{T}$ & $\mathrm{T}$ & $\mathrm{T}$ & $\mathrm{C}$ & $\mathrm{T}$ & $\mathrm{T}$ & $\mathrm{T}$ & $\mathrm{T}$ & $\mathrm{T}$ & $\mathrm{C}$ & $\mathrm{T}$ \\
\hline CMRGV & $\mathrm{T}$ & $\mathrm{C}$ & Y C & G & G & $\mathrm{T}$ & $\mathrm{T}$ & $\mathrm{C}$ & $\mathrm{C}$ & $\mathrm{C}$ & G & $\mathrm{T}$ & $\mathrm{C}$ & $\mathrm{C}$ & $\mathrm{T}$ & $\mathrm{G}$ & $\mathrm{G}$ & $\mathrm{T}$ & $\mathrm{T}$ & $\mathrm{T}$ & $\mathrm{T}$ & $\mathrm{T}$ & $\mathrm{C}$ & $\mathrm{T}$ & $\mathrm{T}$ & $\mathrm{T}$ & $\mathrm{T}$ & $\mathrm{T}$ & $\mathrm{C}$ & $\mathrm{T}$ \\
\hline CMKEW & $\mathrm{T}$ & $\mathrm{C}$ & Y & G & G & $\mathrm{T}$ & $\mathrm{T}$ & $\mathrm{C}$ & $\mathrm{C}$ & $\mathrm{C}$ & G & $\mathrm{T}$ & $\mathrm{C}$ & $\mathrm{C}$ & $\mathrm{T}$ & G & G & $\mathrm{T}$ & $\mathrm{T}$ & $\mathrm{T}$ & $\mathrm{T}$ & $\mathrm{T}$ & $\mathrm{C}$ & $\mathrm{T}$ & $\mathrm{T}$ & $\mathrm{T}$ & $\mathrm{T}$ & $\mathrm{T}$ & $\mathrm{C}$ & $\mathrm{T}$ \\
\hline CJA98 & $\mathrm{C}$ & $\mathrm{T}$ & $\mathrm{CO}$ & G & G & $\mathrm{G}$ & $\mathrm{C}$ & $\mathrm{T}$ & $\mathrm{T}$ & $\mathrm{C}$ & G & G & $\mathrm{C}$ & $\mathrm{G}$ & $\mathrm{C}$ & A & A & $\mathrm{C}$ & $\mathrm{C}$ & $\mathrm{C}$ & $\mathrm{C}$ & G & $\mathrm{T}$ & $\mathrm{C}$ & $\mathrm{G}$ & $\mathrm{C}$ & $\mathrm{C}$ & $\mathrm{C}$ & $\mathrm{T}$ & $\mathrm{C}$ \\
\hline CJQBG & $\mathrm{C}$ & $\mathrm{T}$ & $\mathrm{CA}$ & A & G & G & $\mathrm{C}$ & $\mathrm{T}$ & $\mathrm{T}$ & $\mathrm{C}$ & G & G & $\mathrm{C}$ & G & $\mathrm{C}$ & A & A & $\mathrm{C}$ & $\mathrm{C}$ & $\mathrm{C}$ & $\mathrm{C}$ & G & $\mathrm{T}$ & $\mathrm{C}$ & $\mathrm{G}$ & $\mathrm{C}$ & $\mathrm{C}$ & $\mathrm{C}$ & $\mathrm{T}$ & $\mathrm{C}$ \\
\hline CJA87 & $\mathrm{C}$ & $\mathrm{Y}$ & $\mathrm{CA}$ & A & $\mathrm{G}$ & G & $\mathrm{C}$ & $\mathrm{T}$ & $\mathrm{T}$ & $\mathrm{C}$ & G & G & $\mathrm{C}$ & $\mathrm{G}$ & $\mathrm{C}$ & A & A & $\mathrm{C}$ & $\mathrm{C}$ & $\mathrm{C}$ & $\mathrm{C}$ & G & $\mathrm{T}$ & $\mathrm{C}$ & $\mathrm{R}$ & $\mathrm{C}$ & $\mathrm{C}$ & $\mathrm{C}$ & $\mathrm{T}$ & $\mathrm{C}$ \\
\hline $\mathrm{CAG}$ & $\mathrm{C}$ & $\mathrm{Y}$ & $\mathrm{CA}$ & A & G & $\mathrm{G}$ & $\mathrm{C}$ & $\mathrm{T}$ & $\mathrm{T}$ & $\mathrm{C}$ & G & G & $\mathrm{C}$ & G & $\mathrm{C}$ & A & A & $\mathrm{C}$ & $\mathrm{C}$ & $\mathrm{C}$ & $\mathrm{C}$ & G & $\mathrm{T}$ & $\mathrm{C}$ & $\mathrm{R}$ & $\mathrm{C}$ & $\mathrm{C}$ & $\mathrm{C}$ & $\mathrm{T}$ & $\mathrm{C}$ \\
\hline CMW & $\mathrm{C}$ & $\mathrm{Y}$ & $\mathrm{CA}$ & & G & $\mathrm{G}$ & $\mathrm{C}$ & $\mathrm{T}$ & $\mathrm{T}$ & $\mathrm{C}$ & $\mathrm{G}$ & G & $\mathrm{C}$ & $\mathrm{G}$ & $\mathrm{C}$ & A & A & $\mathrm{C}$ & $\mathrm{C}$ & $\mathrm{C}$ & $\mathrm{C}$ & G & $\mathrm{T}$ & $\mathrm{C}$ & $\mathrm{R}$ & $\mathrm{C}$ & $\mathrm{C}$ & $\mathrm{C}$ & $\mathrm{T}$ & $\mathrm{C}$ \\
\hline CCBG & $\mathrm{C}$ & $\mathrm{Y}$ & $\mathrm{C} A$ & A & A & $\mathrm{G}$ & $\mathrm{C}$ & C & $\mathrm{T}$ & C & A & G & $\mathrm{T}$ & G & $\mathrm{C}$ & A & A & $\mathrm{C}$ & $\mathrm{C}$ & $\mathrm{C}$ & $\mathrm{C}$ & G & $\mathrm{T}$ & $\mathrm{C}$ & $\mathrm{R}$ & $\mathrm{C}$ & $\mathrm{C}$ & $\mathrm{C}$ & $\mathrm{T}$ & $\mathrm{C}$ \\
\hline CTW & $\mathrm{C}$ & $\mathrm{Y}$ & $\mathrm{C} \mathrm{F}$ & $\mathrm{R}$ & G & G & $\mathrm{C}$ & $\mathrm{T}$ & $\mathrm{T}$ & $\mathrm{C}$ & G & G & Y & G & $\mathrm{C}$ & A & A & $\mathrm{C}$ & $\mathrm{C}$ & $\mathrm{C}$ & $\mathrm{C}$ & G & $\mathrm{T}$ & $\mathrm{C}$ & G & $\mathrm{C}$ & $\mathrm{C}$ & $\mathrm{C}$ & $\mathrm{T}$ & $\mathrm{C}$ \\
\hline
\end{tabular}




\section{Discussion}

As reviewed in the introduction, $C$. magnificum differs from $C$. japonicum in several morphological characters. Within each species, nrDNA ITS sequences diverge little ( $0 \%$ to $0.7 \%$ ), while between these two species sequences are approximately five times more divergent $(3.4 \%$ to $4 \%$, Table 3$)$. These results, together with morphology, support the treatment of $C$. japonicum and C. magnificum as separate species. Additionally, our sequence data demonstrate that these four weeping katsura, regardless of their origin or habit, are C. japonicum and not C. magnificum.

Although some speculate that weeping Cercidiphyllum may be a hybrid between $C$. japonicum and C. magnificum (Spongberg, 1979), it is unlikely that this is the case. Sequences of nrDNA ITS in this study show significant differences between $C$. japonicum and C. magnificum $(3.4 \%$ to $4 \%$, Table 3 ). However, in sites that have different nucleotides between these two species, sequences of weeping Cercidiphyllum do not show any base additivity that might indicate hybrid origin (Del Tredici and Li, 2002) (Table 2).

Because our data and results confirm that all pendulous katsura trees be placed within $C$. japonicum, it is essential that distinct genotypes be recognized and easily referenced. In accordance with Articles 4 and 19 of the International Code of Nomenclature for Cultivated Plants (ICNCP) (Trehane et al., 1995), we propose a new cultivar-group Cercidiphyllum japonicum Weeping Group to include all katsura clones of weeping or pendulous habit. Cultivar epithets cannot be duplicated within the same denomination class under ICNCP Articles 6.1 and 14.4 (Trehane et al., 1995). Thus, we support the application of the cultivar name $C$. japonicum 'Morioka Weeping' (Del Tredici, 2000) to the excurrent and upright, pendulous clone described previously by Koller (1987) as C. magnificum 'Pendulum' (obtained from an historic Japanese tree and distributed by the Arnold Arboretum). This epithet, 'Morioka Weeping', should also apply to identical clones that may have been propagated from this or other monumental trees and cultivated. The cultivar epithet 'Pendulum', as applied to a weeping clone of rounded form, should be preserved as such in accordance with ICNCP Articles 10.1 and 14.3 (Trehane et al., 1995). The cultivars 'Amazing Grace' and 'Tidal Wave', although also of similar rounded form, display sufficient marked differences as described by Cappiello (1999) and Barnes (1995), respectively, to have their cultivar epithets likewise preserved.

\section{Literature Cited}

Andrews, S. 1998. Tree of the year: Cercidiphyllum japonicum. Intl. Dendrol. Soc. Yrbk. 1997:1746.

Angiosperm Phylogeny Group. 1998. An ordinal classification for the families of flowering plants. Ann. Missouri Bot. Gard. 85:531-553.

Baldwin, B.G., M.J. Sanderson, J.M. Porter, M.F.

Wojciechowski, C.S. Campbell, and M.J.
Table 3. Sequence divergence (\%) of nrDNAITS in Cercidiphyllum japonicum, Cercidiphyllum magnificum, and weeping Cercidiphyllum, calculated in PAUP*. Acronyms for samples are listed in Table 1.

\begin{tabular}{|c|c|c|c|c|c|c|c|c|c|c|c|c|}
\hline & Sample & 1 & 2 & 3 & 4 & 5 & 6 & 7 & 8 & 9 & 10 & 11 \\
\hline$\overline{1}$ & CME18 & --- & & & & & & & & & & \\
\hline 2 & CME19 & 0.0 & --- & & & & & & & & & \\
\hline 3 & CMRGV & 0.3 & 0.1 & --- & & & & & & & & \\
\hline 4 & CMKEW & 0.3 & 0.1 & 0.0 & --- & & & & & & & \\
\hline 5 & CJA98 & 3.7 & 3.6 & 3.7 & 3.7 & --- & & & & & & \\
\hline 6 & CJQBG & 3.9 & 3.7 & 3.9 & 3.9 & 0.1 & --- & & & & & \\
\hline 7 & CJA87 & 3.7 & 3.6 & 3.7 & 3.7 & 0.2 & 0.0 & --- & & & & \\
\hline 8 & CAG & 3.7 & 3.6 & 3.7 & 3.7 & 0.2 & 0.0 & 0.0 & --- & & & \\
\hline 9 & CMW & 3.7 & 3.6 & 3.7 & 3.7 & 0.2 & 0.0 & 0.0 & 0.0 & --- & & \\
\hline 10 & CCBG & 4.0 & 3.9 & 4.0 & 4.0 & 0.7 & 0.6 & 0.6 & 0.6 & 0.6 & --- & \\
\hline 11 & CTW & 3.6 & 3.4 & 3.6 & 3.6 & 0.0 & 0.0 & 0.0 & 0.0 & 0.0 & 0.5 & --- \\
\hline
\end{tabular}
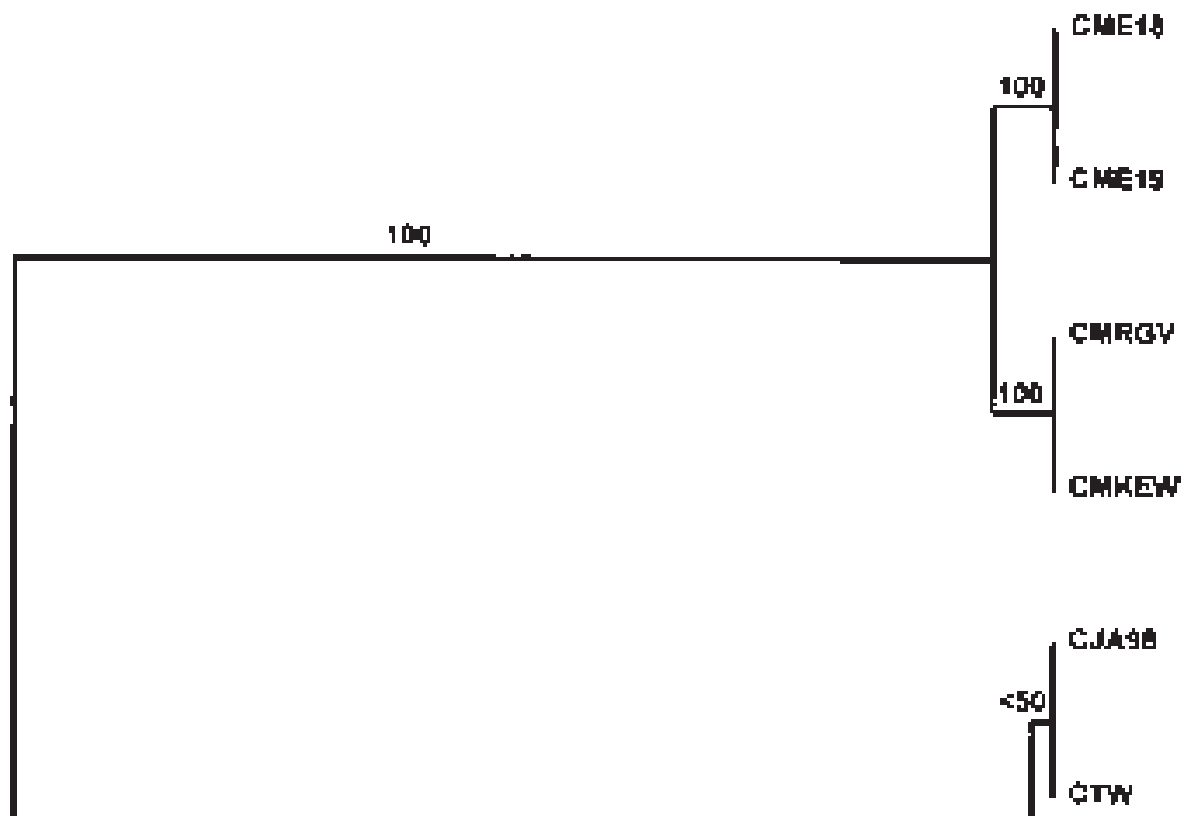

(to

CHADE

†새요

CAG

$+4$

Ghint

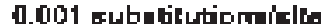

CERE

Fig. 1. Phylogram showing genetic relationships of Cercidiphyllumjaponicum, Cercidiphyllum magnificum, and weeping Cercidiphyllum generated using nrDNA ITS sequences data and the UPGMA method. Numbers above branches represent percentages of bootstrap support. Acronyms for samples are listed in Table 1 . 
Donoghue. 1995. The ITS region of nuclear ribosomal DNA: A valuable source of evidence on angiosperm phylogeny. Ann. Missouri Bot. Gard. 82:247-277.

Barnes, H.W. 1995. New and unusual plants worthy of use and propagation. Proc. Intl. Plant Prop. Soc. 45:513-516.

Baum, D.A., R.L. Small, and J.F. Wendel. 1998. Biogeography and floral evolution of baobabs (Adansonia, Bombacaceae) as inferred from multiple data sets. Syst. Biol. 47:181-207.

Bean, W.J. 1970. Trees \& shrubs hardy in the British Isles. Vol. 1. 8th ed. John Murray, London.

Cappiello, P.E. 1999. Cercidiphyllum japonicum 'Amazing Grace' a new weeping katsura selection from Theodore Klein. Proc. Intl. Plant Prop. Soc. 49:381.

Del Tredici, P. 2000. Woody plants, a blast from the past. Amer. Nurseryman 192(9):56-63.

Del Tredici, P. and J. Li. 2002. Stewartia X 'Scarlet Sentinel'. HortScience 37:412-414.

Dirr, M.A. 1998. Manual of woody landscape plants: Their identification, ornamental characteristics, culture, propagation, and uses. 5th ed. Stipes, Champaign, Ill.

Dosmann, M.S. 1999. Katsura: A review of Cercidiphyllum in cultivation and in the wild. New Plantsman 6:52-62.

Dosmann, M.S. 2000. Cercidiphyllum magnificum. Amer. Nurseryman 191(7):142.

Endress, P.K. 1986. Floral structure, systematics and phylogeny in Trochodendrales. Ann. Missouri Bot. Gard. 73:297-324

Felsenstein, J. 1985. Confidence limits on phylogenies: An approach using the bootstrap. Evolution 39:783-791.

Flint, H.L. 1997. Landscape plants for eastern North America. 2nd ed. Wiley, New York.

Gawel, N.J., G.R. Johnson, and R. Sauve. 1996. Identification of genetic diversity among Loropetalum chinense var. rubrum introductions. J. Environ. Hort. 14:38-41.

Gould, K. and M.J. Donoghue. 2000. Phylogeny and biogeography of Triosteum (Caprifoliaceae). Harvard Pap. Bot. 5:157-166.
Griffiths, M. 1994. Index of garden plants. Timber Press, Portland.

Haag, R. 1982. The magnificent katsura: Tree of the future. Univ. Wash. Arb. Bul. 45:2-5.

Harms, H. 1916. Über die Blüthenverhältnisse und die Systematische Stellung der Gattung Cercidiphyllum Sieb. \& Zucc. Ber. Deutsch. Bot. Ges. 34:272-283.

Hoffman, J. and H. Schultes. 1853. Noms indigenes d'un choix de plantes du Japon et de la Chine. Imprimerie Imperiale, Paris.

Koller, G.L. 1987. Cercidiphyllum magnificum 'Pendulum'. The Public Garden 2(1):17.

Krüssmann, G. 1965. Die Laubgehölze. Verlag Paup Parey, Berlin.

Lancaster, R. 1997. Cercidiphyllum magnificum. J. Royal Hort. Soc. 122:720-721.

Le Duc, A., R.P. Adams, and M.Zhong. 1999. Using random amplification of polymorphic DNA for a taxonomic reevaluation of Pfitzer junipers. HortScience 34:1123-1125.

Li, J.-H., A.L. Bogle, and A.S. Klein. 1999. Phylogenetic relationships of the Hamamelidaceae inferred from sequences of internal transcribed spacers (ITS) of nuclear ribosomal DNA. Amer. J. Bot. 86:1027-1037.

Li, J.-H., A.L. Bogle, A.S. Klein, and M.J. Donoghue. 2000. Phylogeny and biogeography of Hamamelis (Hamamelidaceae). Harvard Pap. Bot. 5:171-178.

Lindquist, B. 1954. Notes on Cercidiphyllum magnificum Nakai. Bot. Tiddsskr. 51:212-219.

Makino, T. 1931. Flora of Japan. Shunyodo, Tokyo (in Japanese)

Manos, P.S., K.C. Nixon, and J.F. Doyle. 1993 Cladistic analysis of restriction site variation within the chloroplast DNA inverted repeat region of selected Hamamelididae. Syst. Bot. 18:551-562.

Miyoshi, M. 1936. Giant and noted trees of Japan, preserved by law, designated as national monuments. Tokoshoin, Tokyo (in Japanese).

Nakai, T. 1919. A new variety of Cercidiphyllum japonicum. Bot. Mag. 33:198

Nakai, T. 1920. Catalogus seminum et sporarum
Hortus Botanicus Universitatis Imperialis Tokyoensis. Univ. Imp., Tokyo

Ohwi, J. 1953. Flora of Japan. Shibundo, Tokyo (in Japanese)

Padgett, D.J., D.H. Les, and G.R. Crow. 1999. Phylogenetic relationships in Nuphar (Nymphaeaceae): Evidence from morphology, chloroplast DNA, and nuclear ribosomal DNA. Amer. J. Bot. 86(9):1316-1324.

Qiu, Y.-L., M. Chase, S.B. Hoot, E. Conti, P.R Crane, K.J. Sytsma, and C.R. Parks. 1998. Phylogenetics of the Hamamelidae and their allies: Parsimony analyses of nucleotide sequences of the plastid gene $r b c \mathrm{~L}$. Intl. J. Pl. Sci. 159:881-890.

Qiu, Y.L., J.H. Lee, F. Bernasconi-Quadroni, D.E Soltis, P.S. Soltis, M. Zanis, E.A. Zimmer, Z.D Chen, V. Savolainen, and M.W. Chase. 1999. The earliest angiosperms: Evidence from mitochondrial, plastid and nuclear genomes. Nature 402:404-407.

Soltis, D.E. and P.S. Soltis. 1997. Phylogenetic relationships in Saxifragaceae sensu lato-A comparison of topologies based on 18S rDNA and $r b c L$ sequences. Amer. J. Bot. 84:504522

Spongberg, S.A. 1979. Cercidiphyllaceae hardy in temperate North America. J. Arnold Arb. 60:367-

Swofford, D.L. 2000. PAUP*. Phylogenetic analysis using parsimony (* and other methods) Sinauer Assoc., Sunderland, Mass.

Trehane, P., C.D. Brickell, B.R. Baum, W.L.A. Hetterscheid, A.C. Leslie, J. McNeill, S.A Spongberg, and F. Vrugtman (editorial committee). 1995. International code of nomenclature for cultivated plants. Quarterjack Publ., Wimborne, U.K.

White, T.J., T. Bruns, S. Lee, and J. Taylor. 1990 Amplification and direct sequencing of fungal ribosomal RNA genes for phylogenetics, p. 315322. In: M. Innis, D. Gelfand, J. Sninsky, and T. White (eds.). PCR protocols: A guide to methods and applications. Academic Press, San Diego 